\title{
Avian erythrocyte agglutination tests with the sera of bird fanciers
}

\author{
J. A. DIMENT AND J. PEPYS
}

From the Department of Clinical Immunology, Cardiothoracic Institute, Brompton, London SW3 $6 H P$

SUMMARY The agglutination of avian red cells, particularly pigeon and budgerigar cells, by sera from patients who had been exposed to birds and had respiratory symptoms, as well as from healthy bird fanciers, has been used to detect the presence of avian specific antibody. Agglutination tests performed by standard techniques using bird erythrocytes can be read within 45 minutes. One hundred and sixty-five sera were tested, and the 44 which were precipitin positive gave a positive agglutination test with one exception. Of 61 sera which gave positive agglutination tests, 43 gave positive precipitin tests with unconcentrated serum and seven others after fourfold concentration of the serum. Avian antibodies were demonstrated in the remaining 11 sera by radioimmunoelectrophoretic tests. Absorption of the sera with pigeon IgG and IgM and the use of animal antisera directed against pigeon IgG showed that the agglutination reactions were mediated by antibodies directed against pigeon IgG and IgM, and against light chains derived from pigeon IgG.

Bird fancier's lung is a respiratory disease associated with the inhalation of dusts of avian materials by persons who keep birds (Barboriak et al., 1965; Reed et al., 1965; Hargreave et al., 1966; Faux et al., 1971). The sensitized subjects develop antibodies against a variety of antigens (Faux et al., 1971; Berrens and Maesen, 1972), the major ones usually being directed against the bird serum albumins and globulins (Edwards et al., 1970; Faux et al., 1971). Radioimmunoassays have been developed to measure antibodies to both pigeon albumin (Hargreave et al., 1974) and pigeon IgG (Nielsen et al., 1974), but these are multistage procedures and not suitable for routine use. Haemagglutination of sheep red cells coated with avian serum proteins is yet another convenient and sensitive method for detecting avian specific antibody (Faux et al., 1971). There is also a report that the serum of two patients with bird fancier's lung agglutinated pigeon, budgerigar, and chicken red blood cells (Bach et al., 1971). Further studies have been made of the latter simple test which has the additional advantage of rapidity because of the speed with which nucleated avian red blood cells settle in agglutination tests (Cayzer et al., 1974).

\section{Material and methods}

\section{HUMAN SERA}

Blood from patients attending the routine allergy

Received for publication 19 May 1976 clinics at the Brompton Hospital was allowed to clot at room temperature overnight and the serum was removed after centrifugation. Other sera were sent for testing by clinicians in other parts of the United Kingdom and Europe. Sera from healthy blood donors who were asked to fill in a questionnaire on their history of bird exposure were used as controls.

\section{BIRD ERYTHROCYTES}

Pigeon and budgerigar cells were obtained by amputating the wing of a bird which had been anaesthetized with ether and collecting the blood in Alsever's solution, or by direct cardiac puncture in the pigeon. The yield was increased by prior intraperitoneal administration of heparin (Evans Medical, Speke, Liverpool), 100 units for a budgerigar and 250 units for a pigeon. The cells were used after several washings in phosphate buffered saline, $\mathrm{pH} \mathbf{7 \cdot 2}$ (PBS), or stored in Alsever's solution containing thiomersal $(0 \cdot 1 \mathrm{~g} / \mathrm{l})$. They were stored for up to two weeks at $4^{\circ} \mathrm{C}$, and were washed several times with PBS immediately before use. Adult chicken red blood cells were purchased from Tissue Culture Services (Slough, England) and turkey red blood cells were obtained from a local turkey farmer.

Pigeon red blood cells were formalinized using the method described by Csizmas (1960).

ANIMAL ANTISERA

Rabbit anti-pigeon serum, rabbit anti-budgerigar 
serum, and rabbit anti-hen serum were purchased from Bio-Service (Tower Hill, London). Antipigeon IgG was raised in an adult Portland Wistar Cross rat by a primary intramuscular injection of pigeon IgG $(0.25 \mathrm{mg}$ in an emulsion of $0.2 \mathrm{ml}$ of saline and $0.2 \mathrm{ml}$ of complete Freund's adjuvant) followed by a booster after one month with the same quantity of antigen in incomplete Freund's adjuvant. The animal was bled two weeks later.

PIGEON AND BUDGERIGAR GLOBULINS

Pigeon macroglobulin was isolated as described by Faux et al. (1971) on Sephadex G-150. Pigeon and budgerigar IgG were prepared by precipitation of other proteins with caprylic acid followed by adsorption with DEAE-cellulose (Steinbuch and Audran, 1969). Both these materials showed one arc on immunoelectrophoresis after diffusion against rabbit anti-pigeon serum and rabbit anti-budgerigar serum respectively.

PIGEON IgG LIGHT CHAINS

Pigeon IgG was reduced with mercaptoethanol, alkylated with iodoacetamide, and chromatographed on Sephadex G-75 in $1 \mathrm{M}$ acetic acid (Fleischman et al., 1962). The material eluted in the second peak was homogeneous with a molecular weight of about 25000 on gradient polyacrylamide gel electrophoresis.

\section{PIGEON AND HEN ALBUMIN}

Pigeon albumin was isolated in poor yield by passing pigeon serum through a blue dextran-Sepharose column followed by elution of the retained material with 6 M urea (Travis and Pannell, 1973). The urea was removed by exhaustive dialysis and the material was lyophilized. Hen albumin was obtained from Miles Laboratories (Stoke Poges, Buckinghamshire). Both these materials showed one arc in the albumin region on immunoelectrophoresis and diffusion against rabbit anti-pigeon serum and rabbit antihen serum respectively.

AVIAN ERYTHROCYTE AGGLUTINATION TEST Standard U-bottomed, rigid, disposable microtitre plates, loops $(0.05 \mathrm{ml})$, and pipettes $(0.05 \mathrm{ml})$ were employed. One drop of $1 \%$ horse serum in PBS was added to each well, followed by $0.05 \mathrm{ml}$ of patient serum to the first well, and then by doubling dilutions for successive wells. Red blood cells at a concentration of $1 \%$ in PBS were then added to each well. The plates were allowed to stand and were read after 40 minutes. Absorption tests we: ${ }^{-}$made by adding the antigen to the initial PBS-horse serum in every well. The concentrations used are shown in Table 6.

A control serum of known titre and a negative

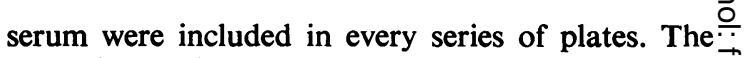
control negative serum was a pool from healthy $\underset{\vec{F}}{\vec{P}}$ blood donors who reported no or little bird exposureand whose sera gave agglutination titres in the upper $\frac{\bar{\sigma}}{\bar{\sigma}}$ range for this group.

DOUBLE-DIFFUSION AND IMMUNOELECTRO- $\frac{\Omega}{\infty}$
PHORESIS

The Ouchterlony agar-gel method (Pepys et al., 1964)웅 was modified for precipitin testing so that the central $\vec{\overrightarrow{ }}$ well in $5 \mathrm{~mm}$ thick agar was $6 \mathrm{~mm}$ in diameter and was $2 \mathrm{~mm}$ distant margin to margin from the peripheral antigen well which was $3 \mathrm{~mm}$ in diameter. This method, adopted for reasons of economy of the. budgerigar serum, is less sensitive than the previous $\overrightarrow{-}$ method in which the corresponding dimensions in 6 $6 \mathrm{~mm}$ thick agar were $13 \mathrm{~mm}, 4 \mathrm{~mm}$, and $4 \mathrm{~mm}$. Immunoelectrophoresis was done on agarose (BDH, Poole, Dorset) using Svenson's buffer (Weeke, 1973). Indirect radioimmunoelectrophoretic tests were made, the patients' IgG, IgA, and IgM being immobilized in the gel by an anti-human immuno- globulin serum (Hyland, Thetford, Norfolk). This was followed by addition to the troughs of, or by $v$ immersing the whole plate in, pigeon or budgerigar IgG (labelled with ${ }^{125}$ I by the chloramine-T method (Hunter, 1974)), in 30\% horse serum as the carrier $\overline{\bar{O}}$ protein solution. After standing overnight, the platesू๊ were washed for one to two days in saline plus $0.05 \%$ Tween 20 (Koch-Light, Colnbrook Buckingham- $\overrightarrow{\overrightarrow{0}}$ shire), then dried, stained, and exposed to $x$-ray 3 films for a suitable time.

Where necessary, $2 \mathrm{ml}$ samples of sera were con-0 centrated by lyophilization and were reconstituted in $0.5 \mathrm{ml}$ of water.

POLYACRYLAMIDE ELECTROPHORESIS This was performed on gradient gels according to the methods suggested by the manufacturer (Pharmacia, Uppsala, Sweden). Chymotrypsinogen A, bovine? serum albumin, and aldolase (molecular weights $\frac{D}{O}$ 25000,67000 , and 158000 respectively) (Boehringer=. Mannheim, Ealing, London) were used as standardsస్ to estimate molecular weights.

\section{Results}

TEST VARIATIONS AND THEIR CONTROL

Table 1 shows the agglutination titres of the different叟 avian erythrocytes by the sera of selected bird ${ }^{+}$ fanciers. Pigeon and budgerigar cells gave the highest titres. Chicken erythrocytes gave low titres with these bird fanciers as well as with rabbit anti-chicken serum? antiserum (Table 2). The use of erythrocytes frome individual birds and ageing of the cells caused some variation in agglutination titres with the patients' 
sera. Small differences in the concentration of red cells used in the test also contributed to inter-test variation. The test variation was not greater than two twofold dilutions for pigeon cells and one twofold dilution for budgerigar cells. Differences were also observed in the ability of serum from apparently unexposed subjects to agglutinate these erythrocytes. Sera were rated positive when they gave titres greater than fourfold above the control with pigeon cells and greater than twofold with budgerigar cells. This usually meant that a titre of 64 or upwards was regarded as positive with pigeon cells and a titre of 32 as positive with budgerigar cells.

\section{AGGLUTINATION TITRES OF AVIAN}

ERYTHROCYTES WITH THE SERA OF PATIENTS

AND HEALTHY BIRD FANCIERS

Agglutination titres of the sera of a group of patients

Table 1 Avian erythrocyte agglutination by selected bird fancier's sera: titre

\begin{tabular}{|c|c|c|c|c|}
\hline Avian species & $\begin{array}{l}\text { Patient } C \\
\text { Pigeon fancier }\end{array}$ & $\begin{array}{l}\text { Patient } H \\
\text { Pigeon fancier }\end{array}$ & $\begin{array}{l}\text { Patient Th } \\
\text { Budgerigar fancier }\end{array}$ & $\begin{array}{l}\text { Median of pooled } \\
\text { negative serum }\end{array}$ \\
\hline $\begin{array}{l}\text { Pigeon rbc } \\
\text { Formalinized pigeon rbc } \\
\text { Budgerigar rbc } \\
\text { Chicken rbc } \\
\text { Turkey rbc }\end{array}$ & $\begin{array}{r}1028 \\
128 \\
512 \\
8 \\
64\end{array}$ & $\begin{array}{r}2048 \\
256 \\
256 \\
64 \\
256\end{array}$ & $\begin{array}{r}512 \\
128 \\
4096 \\
64 \\
128\end{array}$ & $\begin{array}{r}16 \\
8 \\
4 \\
2 \\
2\end{array}$ \\
\hline
\end{tabular}

Table 2 Avian erythrocyte agglutination by antisera to avian serum proteins: titre

\begin{tabular}{lcccc}
\hline Avian species & $\begin{array}{l}\text { Rabbit anti-pigeon } \\
\text { serum }\end{array}$ & $\begin{array}{l}\text { Rabbit anti-budgerigar } \\
\text { serum }\end{array}$ & $\begin{array}{l}\text { Rabbit anti-chicken } \\
\text { serum }\end{array}$ & $\begin{array}{l}\text { Rat anti-pigeon } \\
\text { IgG }\end{array}$ \\
\hline Pigeon rbc & 1024 & 1024 & 512 & 128 \\
Formalinized pigeon rbc & 128 & na & na & na \\
Budgerigar rbc & 128 & 128 & 64 & 4 \\
Chicken rbc & 8 & 8 & 64 & na \\
Turkey rbc & 8 & 16 & 32 & 32 \\
\hline
\end{tabular}

na $=$ not available.

Table 3 Pigeon erythrocyte agglutination titres with sera of (1) exposed patients with respiratory symptoms, and (2) healthy bird fanciers

\begin{tabular}{lccccc}
\hline Exposed mainly to & No. of sera & Agglutination titre \\
\cline { 3 - 6 } & \multicolumn{2}{c}{ Below 64 } & 64,128 & 256,512 & Above 512 \\
\hline Patients & 34 & 11 & 3 & 10 & 10 \\
Pigeon & 47 & 35 & 7 & 2 & 3 \\
Budgerigar & 9 & 8 & 1 & 0 & 0 \\
Other birds & 11 & 5 & 3 & 3 & 0 \\
Healthy fanciers & 26 & 26 & 0 & 0 & 0 \\
Pigeon & 1 & 1 & 0 & 0 & 0 \\
Budgerigar & 1 & Other birds & &
\end{tabular}

ITen of the 11 had been pigeon fanciers for more than five years.

Table 4 Budgerigar erythrocyte agglutination titres with sera of (1) exposed patients with respiratory symptoms, and (2) healthy bird fanciers

\begin{tabular}{|c|c|c|c|c|c|}
\hline \multirow[t]{2}{*}{ Exposed mainly to } & \multirow[t]{2}{*}{ No. of sera } & \multicolumn{4}{|c|}{ Agglutination titre } \\
\hline & & Below 32 & 32,64 & 128,256 & Above 256 \\
\hline \multicolumn{6}{|l|}{ Patients } \\
\hline Pigeon & 34 & 12 & 3 & 9 & 10 \\
\hline Budgerigar & 47 & 35 & 6 & 2 & 4 \\
\hline Other birds & 9 & 8 & 1 & 0 & 0 \\
\hline \multicolumn{6}{|l|}{ Healthy fanciers } \\
\hline Pigeon 1 & 11 & 5 & 3 & 3 & 0 \\
\hline Budgerigar & 26 & 26 & 0 & 0 & 0 \\
\hline Other birds & 1 & 1 & 0 & 0 & 0 \\
\hline
\end{tabular}

${ }^{1}$ Ten of the 11 had been pigeon fanciers for more than five years. 
who had been referred to the Brompton Hospital with respiratory symptoms and a history of bird exposure are compared with the titres of the sera from a group of healthy bird fanciers in Table 3 using pigeon cells, and in Table 4 using budgerigar cells. In the bird fanciers with respiratory disease, raised agglutination titres to pigeon erythrocytes were given by $67 \%$ of the pigeon fanciers and by $28 \%$ of budgerigar fanciers. Raised agglutination titres against budgerigar erythrocytes were given by $65 \%$ of the pigeon fanciers and by $26 \%$ of the budgerigar fanciers. Of the healthy pigeon fanciers, $54 \%$ gave raised but lower titres to both pigeon and budgerigar erythrocytes. None of the healthy budgerigar fanciers had raised titres to either pigeon or budgerigar erythrocytes.

Table 5 shows that the pigeon erythrocytes gave more agglutination reactions with the sera which had

Table 5 Comparison of agglutination/precipitin tests on 165 bird fanciers' sera

\begin{tabular}{llll}
\hline $\begin{array}{llll}\text { Precipitin test } \\
\text { positive to: }\end{array}$ & No. of sera & \multicolumn{2}{l}{ Agglutination test positive } \\
\cline { 2 - 4 } & & $\begin{array}{l}\text { Pigeon } \\
\text { rbc }\end{array}$ & $\begin{array}{l}\text { Budgerigar } \\
\text { rbc }\end{array}$ \\
\hline Pigeon serum & 44 & 43 & 34 \\
Budgerigar serum & 41 & 40 & 32 \\
\hline
\end{tabular}

given precipitin positive reactions without concentration in the Ouchterlony test. Further tests on 19 sera where negative agar-gel precipitin tests were given initially, and where positive agglutination titres were given to either pigeon or budgerigar erythrocytes, showed that seven gave positive precipitin tests after fourfold concentration of the serum, and 11 showed binding of either pigeon or budgerigar IgG on radioimmunoelectrophoresis. The remaining serum, which had an agglutination titre of 64 to pigeon erythrocytes, gave negative reactions to the further tests and came from a healthy blood donor with no history of bird exposure.

The serum from one pigeon fancier who had no been exposed to birds for 10 years gave positive precipitin reactions to both pigeon and budgeriga $E$ serum without a raised agglutination titre. On im munoelectrophoresis the serum showed only a single્d arc to pigeon and budgerigar $\beta$-globulin.

\section{ANTIGEN ABSORPTION TESTS}

Tables 6 and 7 show that absorption of the patients' sera with pigeon serum, pigeon gamma globulin, macroglobulin and light chains prepareक from pigeon IgG inhibited the agglutination of pigeon erythrocytes and budgerigar erythrocytes, whereas pigeon and hen albumin had no effect.

\section{Discussion}

We have confirmed the report by Bach et al. (1971) that the sera of bird fanciers can agglutinate rede blood cells from pigeon, budgerigar, and chicken Rabbit anti-pigeon serum, rabbit anti-budgerigar serum, and rabbit anti-chicken serum also agglutin- $-v$ ated the bird erythrocytes. The inhibition of agglu- tination of pigeon and budgerigar cells by absorptiono of the patients' sera with pigeon gammaglobulin and macroglobulin showed that these containedo reacting antigens. The observation that light chainso of pigeon gammaglobulin also inhibited the ag- $\cong$ glutination of pigeon erythrocytes suggests that they were among the antigens with which the antibodies 3 were reacting. Bird fanciers are known to produce? antibodies against antigens in bird droppings which? cross-react with pigeon globulins (Edwards et al. 1970). Rat anti-pigeon gammaglobulin agglutinated? pigeon cells to a titre of 128 , thus confirming the presence of the gammaglobulin or a cross-reacting antigen on the red cells. The possibility that other antigens, such as the $P_{1}$ antigen described by Radermecker et al. (1975), may also contribute to the? agglutination has not been excluded.

Table 6 Absorption of test sera-effect on pigeon erythrocyte agglutination test titres

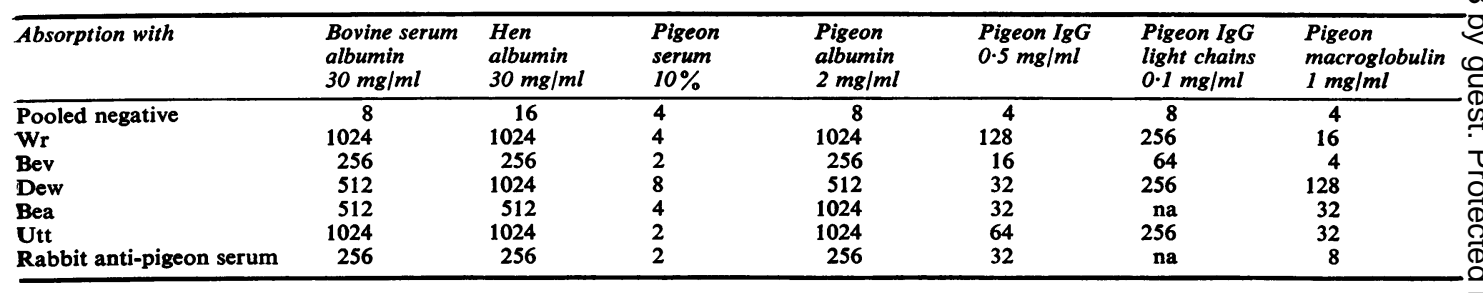


Table 7 Absorption of test sera-effect on budgerigar and turkey erythrocyte agglutination test titres

\begin{tabular}{|c|c|c|c|c|c|c|c|c|}
\hline \multirow{2}{*}{$\begin{array}{l}\text { Absorption } \\
\text { with }\end{array}$} & \multicolumn{4}{|c|}{ Budgerigar rbc agglutination } & \multicolumn{4}{|c|}{ Turkey rbc agglutination } \\
\hline & $\begin{array}{l}\text { Bovine serum } \\
\text { albumin } \\
30 \mathrm{mg} / \mathrm{ml}\end{array}$ & $\begin{array}{l}\text { Pigeon } \\
\text { serum } \\
10 \%\end{array}$ & $\begin{array}{l}\text { Pigeon } \\
\text { IgG } \\
0.5 \mathrm{mg} / \mathrm{ml}\end{array}$ & $\begin{array}{l}\text { Pigeon } \\
\text { macroglobulin } \\
1 \mathrm{mg} / \mathrm{ml}\end{array}$ & $\begin{array}{l}\text { Bovine serum } \\
\text { albumin } \\
30 \mathrm{mg} / \mathrm{ml}\end{array}$ & $\begin{array}{l}\text { Pigeon } \\
\text { serum } \\
10 \%\end{array}$ & $\begin{array}{l}\text { Pigeon } \\
1 \mathrm{gG} \\
0.5 \mathrm{mg} / \mathrm{ml}\end{array}$ & $\begin{array}{l}\text { Pigeon } \\
\text { macroglobulin } \\
1 \mathrm{mg} / \mathrm{ml}\end{array}$ \\
\hline $\begin{array}{l}\text { Wr } \\
\text { Utt } \\
\text { Bev }\end{array}$ & $\begin{array}{l}512 \\
512 \\
521\end{array}$ & $\begin{array}{r}16 \\
4 \\
4\end{array}$ & $\begin{array}{r}32 \\
8 \\
128\end{array}$ & $\begin{array}{r}32 \\
4 \\
64\end{array}$ & $\begin{array}{l}512 \\
512 \\
256\end{array}$ & $\begin{array}{l}32 \\
32 \\
16\end{array}$ & $\begin{array}{r}128 \\
128 \\
32\end{array}$ & $\begin{array}{r}128 \\
128 \\
64\end{array}$ \\
\hline
\end{tabular}

It has been shown by Nielsen et al. (1974) that their assay of antibodies to pigeon 7S gammaglobulin gives a reliable indication of antibody in patients with pigeon fanciers' lung, but they also found that sera of asymptomatic fanciers can give titres which overlap with those of affected fanciers. We obtained similar results, three healthy pigeon fanciers giving agglutination titres in the 256-512 range. Patients with definite evidence of bird fancier's lung had titres in the range 128 to 8192 against pigeon cells and 64 to 4096 against budgerigar cells.

Although the antigen absorption experiments showed that there were similar or related antigens on the different avian red cells, higher titres were given in some cases in tests with pigeon red cells than with those of the species to which the patient had been exposed. It seems that the patient's serum should be tested with pigeon erythrocytes as well as with those of the species to which he had been exposed. The report of an inverse effect of avian red cell concentrations and of ageing of the cells on agglutination titres (Soda et al., 1971) shows that care is needed to ensure comparability of results in repeat tests.

The avian erythrocyte agglutination test described here provides an additional method for detecting antibody in the sera of bird fanciers. The test can be completed within 45 minutes as the settling of nucleated bird erythrocytes is rapid and, in our hands, costs less than precipitin tests using budgerigar serum. The results of the precipitin test correlate well with the agglutination test although the latter appears to be more sensitive in terms of antibodies to the avian immunoglobulins. Of 104 sera which were agglutination positive, 18 were precipitin negative. Antibodies were detected in 17 of these sera by more sensitive radioimmunoassay methods; the remaining serum gave a titre of 64 with pigeon red cells and 16 with budgerigar cells and came from a subject who reported no exposure to birds. The possibility of non-antibody mediated agglutination also has to be considered, as well as the possibility that antibodies may be present against the other avian serum proteins and may not react with the antigens on the red cells. Thus one patient who had antibodies only to a $\beta$-globulin in the precipitin test gave a negative agglutination test.
The use of turkey red blood cells as a support for the coupling of antigens is likely to find increasing use in the routine laboratory. Two such tests have already been described, for Treponemal (Sequeira and Eldridge, 1973) and for hepatitis B antigen (Cayzer et al., 1974). False-positive reactions in terms of these latter antigens may, however, be obtained even after absorption of the sera of pigeon and budgerigar fanciers with turkey erythrocytes.

\section{References}

Bach, C., Fournier, C., Drouhet, E., Texier, J. L., Dardenne, M., Laborde, M. A., and Bach, J. F. (1971). La maladie des éleveurs d'oiseaux chez l'enfant. Presse mêd., 79, 383386.

Barboriak, J. J., Sosman, A. J., and Reed, C. E. (1965). Serological studies in pigeon breeder's disease. J. Lab. clin. Med., 65, 600-604.

Berrens, L. and Maesen, F. P. V. (1972). An immunological study of pigeon-breeder's disease. Int. Arch. Allergy., 43, 289-304.

Cayzer, I., Dane, D. S., Cameron, C. H., and Denning, J. V. (1974). A rapid haemagglutination test for hepatitis-B antigen. Lancet, 1, 947-949.

Csizmas, L. (1960). Preparation of formalinized erythrocytes. Proc. soc. exp. Biol. (N.Y.), 103, 157-161.

Edwards, J. H., Barboriak, J. J., and Fink, J. N. (1970). Antigens in pigeon breeders' disease. Immunology, 19, 729-734.

Faux, J. A., Wells, I. D., and Pepys, J. (1971). Specificity of avian serum proteins in tests against the sera of bird fanciers. Clin. Allergy, 1, 159-170.

Faux, J. A., Wide, L., Hargreave, F. E., Longbottom, J. L., and Pepys, J. (1971). Immunological aspects of respiratory allergy in budgerigar (Melopsittacus undulatus) fanciers. Clin. Allergy, 1, 149-158.

Fleischman, J. B., Pain, R. H., and Porter, R. R. (1962). Reduction of $\gamma$-globulins. Arch. Biochem., Supplement, 1, 174-180.

Hargreave, F. E., Dolovich, J., Poothullil, J., Chiavaro, H., and Debanne, M. T. (1974). Specificities of immune responses in allergic alveolitis from avian antigens. (Abstract). J. Allergy clin. Immunol., 53, 85.

Hargreave, F. E., Pepys, J., Longbottom, J. L., and Wraith, D. G. (1966). Bird breeder's (fancier's) lung. Lancet, 1, 445-449.

Hunter, W. M. (1974). Preparation and assessment of radioactive tracers. Brit. med. Bull., 30, 18-23.

Nielsen, K. H., Parratt, D., Boyd, G., and White, R. G. (1974). Use of radiolabelled antiglobulin for quantitation of antibody to soluble antigens rendered particulate: application to human sera from 'pigeon fancier's lung syndrome'. Int. Arch. Allergy., 47, 339-350.

Pepys, J., Longbottom, J. L., and Jenkins, P. A. (1964) 
Vegetable dust pneumoconioses. Immunological responses to vegetable dusts and their flora. Amer. Rev. resp. Dis., 89, 842-858.

Radermecker, M., Bruwier, M., François, C., Brocteur, J., Salmon, J., André, A., and Van Cauwenberge, H. (1975). Anti- $\mathrm{P}_{1}$ activity in pigeon breeders' serum. Clin. exp. Immunol., 22, 546-549.

Reed, C. E., Sosman, A. J., and Barbee, R. A. (1965). Pigeon-breeder's lung: a newly observed interstitial pulmonary disease. J. Amer. med. Ass., 193, 261-265.

Sequeira, P. J. L., and Eldridge, A. E. (1973). Treponemal haemagglutination test. Brit. J. vener. Dis., 49, 242-248.
Soda, K., Matumoto, M., and Tabata, E. (1971). Erythro-으 cytes of Japanese quail for hemagglutination by rubella virus. Jap. J. Mi robiol., 15, 351-357.

Steinbuch, M. and Audran, R. (1969). The isolation of $\mathrm{IgG}_{-}$ from mammalian sera with the aid of caprylic acid. Arch. Biochem., 134, 279-284.

Travis, J. and Pannell, R. (1973). Selective removal of albumin from plasma by affinity chromatography. Clin. chim. Acta, 49, 49-52.

Weeke, B. (1973). Equipment, reagents and procedures for quantitative immunoelectrophoresis. Scand. J. Immunol., $\vec{O}$ 2, Supplement, 1, 15-35 